HALINA PARAFIANOWICZ (Białystok)

\title{
POMIĘDZY MITEM A RZECZYWISTOŚCIĄ: MIĘDZYWOJENNA AMERYKA W PAMIETNIKACH EMIGRANTÓW ${ }^{1}$
}

Pamiętniki emigrantów ze Stanów Zjednoczonych ${ }^{2}$, będące pokłosiem konkursu ogłoszonego w 1935 r. przez Instytut Gospodarstwa Społecznego, są bardzo interesującym i bogatym źródłem dla historyków i socjologów. Spośród 90 pamiętnikarzy zdecydowana większość była pochodzenia chłopskiego (prawie 70\%), ale w USA jedynie dwóch $\mathrm{z}$ nich (około 2\%) ustabilizowało się jako farmerzy. 48 pamiętnikarzy pracowało jak robotnicy (53\%), $\mathrm{z}$ czego połowa $\mathrm{w}$ czasie spisywania pamiętników w czasie kryzysu gospodarczego była bezrobotna. 27 pamiętnikarzy (około 30\%) reprezentowało amerykańskie warstwy średnie, tj. drobnych kupców i rzemieślników, 6 (niespełna 7\%) - pracowników umysłowych, a tylko jeden reprezentował wolne zawody (lekarz). Warto też dodać, że spośród 90 pamiętnikarzy tylko 12 to kobiety ${ }^{3}$.

Większość pamiętnikarzy przybyła do USA w latach 1900-1914, pozostając tam na stałe. I choć deklarowali oni chęć zarobienia pieniędzy i powrotu do kraju, jednak zdecydowana większość z nich zmieniła potem plany i została w USA. Mimo niekwestionowanej tęsknoty i sentymentów nie powrócili do wolnej już Polski po I wojnie światowej. W Ameryce, po latach ciężkiej pracy i wielu wyrzeczeń, uzyskali oni stabilizację zawodową oraz

1 Jest to poszerzona wersja referatu wygłoszonego 12 listopada 2001 r. w Puławach na dorocznej konferencji Polskiego Towarzystwa Studiów Amerykanistycznych.

2 Pamiętniki emigrantów. Stany Zjednoczone, t. I-II, Książka i Wiedza, Warszawa 1977.

3 Ibidem, t. I, s. 66-68. 
niezłe pobory, co umożliwiało im dostatnie i wygodne życie. W latach dwudziestych, tak jak inni Amerykanie, korzystali z boomu gospodarczego kraju, który stał się dla nich nową ojczyzną. Dopiero wielki światowy kryzys gospodarczy zmienił drastycznie położenie większości z nich, jak również milionów Amerykanów.

Stany Zjednoczone od początku swego istnienia interesowały i intrygowały Europejczyków, w tym również Polaków ${ }^{4}$. Z czasem amerykańska demokracja i jej ideały, a także bogactwo i ogrom odległego kraju stały się obiektem marzeń i fascynacji milionów ludzi na całym świecie. Od II połowy XIX wieku do USA przybyły rzesze emigrantów z Europy Zachodniej i Północnej, a potem także Środkowowschodniej i Południowej. Miliony z nich zrealizowały w ten sposób swoje marzenia - dotarły do kraju wielkiej życiowej szansy, kraju dobrobytu, „amerykańskiego raju”, jak to często określano. Dla milionów innych ludzi na świecie Ameryka pozostanie mityczną krainą „mlekiem i miodem płynącą", krajem przygód, wielkich możliwości i potencjalnego sukcesu oraz kariery w stylu „od pucybuta do milionera”.

Masowa emigracja z ziem polskich „za chlebem” utwierdziła powszechne przekonanie o tej niezwykłej krainie pełnej bogactw, która stwarzała wielkie możliwości dla zwykłych śmiertelników, pracowitych i przedsiębiorczych ludzi. Ameryka stała się obiektem marzeń wielu Polaków, swoistym Eldorado, zwłaszcza dla ludzi biednych, którzy wyobrażali sobie, że dotarcie za ocean da im szansę na dostatnie życie.

Znakomitym tego przykładem jest Stefan Mierzwa, syn chłopa średniorolnego. Swój pierwszy kontakt z Ameryką zapamiętał jako spotkanie z człowiekiem $\mathrm{z}$ jego rodzinnej wsi, który przyjechał zza oceanu i zrobił na nim ogromne wrażenie. Jak wspominał: „Człowiek ten był ubrany w miejski garnitur, miał krochmalony kołnierzyk, szary jedwabny krawat; miał nawet zegarek na prawdziwym złotym łańcuszku. Byłem olśniony tym całym przepychem. I kiedy słuchałem jego całkiem nieprawdopodobnych opowiadań o tym, jak ludzie w Ameryce jadają mięso trzy razy dziennie, mają ciastka, kiedy zechcą, pracują osiem lub dziesięć godzin na dobę i chodzą przynajmniej raz w tygodniu do teatru, wówczas i ja postanowiłem jechać do tej krainy z bajki" 5 .

4 Warto odnotować znakomite dzienniki i reportaże z pobytu w Stanach Zjednoczonych Juliana Ursyna Niemcewicza (Podróze po Ameryce, 1797-1807, Warszawa 1959) oraz Henryka Sienkiewicza, który tam przebywał w latach 1876-1878 (Listy z podróży do Ameryki, Warszawa 1978).

5 Pamiętniki.., t. II, s. 609-610. 
W kilka lat później, w 1910 r., 17-letni Mierzwa odbył podróż morską (za pożyczone pieniądze) i wylądował w Nowym Jorku, który tak zapamiętał: „Od pierwszego mego wejrzenia na Nowy Jork - błyszczący nad wodami portu, jak zaczarowany pałac, utkany z drżących świateł - Ameryka urzeczywistniła wszystkie me marzenia o niej. Pokochałem to potężne miasto z jego tłumami i wrzawą, ponad którymi unosił się nimb świetlny, otaczający taką nieprawdopodobną hojnością i nieopisanym pięknem gród Świata Nowego. Gdzieś po drodze kupiłem sobie pierników - pamiętam dotychczas, jak mi smakowały. Ludzie wszędzie okazywali nam przychylność. Wszyscy, jak gdyby byli w zmowie, starali się nam w czymkolwiek dopomóc. I tak było zawsze. Nigdy też nie doznałem żadnego rozczarowania w Ameryce, przynajmniej nigdy ze strony rzeczywistych Amerykanów" 6. Tu też Stefan Mierzwa zrealizował swoje marzenia. W 1921 roku, dzięki swemu uporowi, determinacji i życzliwości otoczenia, skończył studia ekonomiczne na Uniwersytecie Harvarda, po czym zrobił karierę akademicką. W przyszłości był też zaangażowanym działaczem polonijnym i założycielem, a potem prezesem, Fundacji Kościuszkowskiej.

Większość emigrantów wyjeżdżała z powodów ekonomicznych i chęci dorobienia się w Ameryce. Pisali wprost, że wyjeżdżali, by „zdobyć fortunę”, „Zarobić dużo pieniędzy aby ułatwić sobie życie”, „prędzej się wzbogacić", w tej „ziemi obiecanej” 7 . Warto też dodać, że większość wyjeżdżających nie wiedziała nic, albo prawie nic, o Stanach Zjednoczonych, ich systemie gospodarczo-politycznym i realiach amerykańskiego życia. W zasadzie nie było to dla nich ważne ani potrzebne, mieli bowiem swoje wyobrażenia i marzenia o Ameryce. I to im zupełnie wystarczało. Co więcej, nawet jeśli krewni przebywający w USA pisali czasem, że w Ameryce jest ciężko i nie tak wspaniale, jak się innym zdaje, to i tak nie dawano temu wiary.

Jak wspominała żona murarza $\mathrm{z}$ Detroit, córka chłopa małorolnego z Małopolski, od dzieciństwa marzyła o Ameryce, w której- jak opowiadano - „będzie można złota nazbierać, świat zobaczyć, rodzinie pomóc, nauczyć się czego [...]”. Niecierpliwie więc wyczekiwała na moment wyjazdu, „by się tylko dostać do tej ziemi obiecanej, mlekiem i miodem płynącej, krainy sposobności" ${ }^{8}$. I choć jej życie w Stanach Zjednoczonych nie było zbyt łatwe, zdecydowała się jednak wystąpić o obywatelstwo i pozostać tam na stałe.

6 Ibidem, t. II, s. 611.

7 Ibidem, t. II, s. 231, 299, 393.

8 Ibidem, t. II, s. 440. 
Podkreślała, że warunki mieszkaniowe w USA były dużo lepsze, a życie po prostu wygodniejsze. I kategorycznie stwierdziła, że poziom życia robotnika był "wyższy pod każdym względem" ${ }^{9}$.

Jak pisał z kolei w „spowiedzi swego życia” właściciel sklepu w Indian Orchard, o powodach wyjazdu do USA w 1912 r. zadecydowały... fotografie krewnych z Ameryki. Jak wspominał: „Byli tak ładnie ubrani, że nie mogło mi się w głowie pomieścić, żeby prości robotnicy mogli sobie na to pozwalać. Rozmyślałem długo, co to za dziwny kraj musi być ta Ameryka. Prości ludzie, a noszą się jak urzędnicy w Polsce. Z fotografii widać, że są dobrze odżywieni, a do tego jeszcze pieniądze przysyłaja swym krewnym. Porównywałem to ze stopa życiową prostego robotnika w Polsce a nawet moje uposażenie, które było najmniej sto procent lepsze, niż zwykłego robotnika. Po rozważeniu postanowiłem zaryzykować moje oszczędności na wyjazd do Ameryki, chociażby na zwiedzenie tylko. Przytem sam chciałem popróbować szczęścia za oceanem i na własne oczy zobaczyć ten raj robotników. W razie niepowodzenia planowałem powrócić do Polski, bogaty przynajmniej w doświadczenia" 10.

Jego fantastyczne wyobrażenia o Ameryce potwierdziły się po dotarciu na miejsce. Wspominał potem tak: „Gdy pierwszy raz po przybyciu z Polski poszedłem do kościoła zdumiałem się. Kobiety wystrojone w jedwabie i kapelusze, mężczyźni też ubrani porządnie po miejsku, siedzieli wszyscy w ławkach, gdyż w tutejszych kościołach stojących miejsc nie ma. Wierzyć się nie chciało, że to tylko nasze Wojtki i Kasie przeważnie ze wsi polskich" ${ }^{11}$. Był to dla niego szok, tym silniejszy, że autor tylko co przybył ze „starego kraju".

Inni emigranci również pisali, że powodem ich wyjazdu do USA była chęć zarobienia pieniędzy, wymarzonych dolarów. Robotnik z Chicago wspominał, że wy jechał bo „kto tylko słyszał o Ameryce jechał po złote runo, potrzebował czy nie" i szukał tam „lepszego szczęścia i większego majątku” ${ }^{12}$.

Listonosz z Detroit pisał, że z jego rodzinnych stron (powiat Oszmiana na Wileńszczyźnie) wielu wyjeżdżało do Ameryki i „każdemu jakoś się powodziło lepiej niżeli w kraju, to i na mnie działało, że może prędzej dorobić się niżeli w domu". I to zadecydowało o jego wyjeździe w 1912 r. do USA, gdzie osiadł na stałe i pozostał do końca życia. Jak pisał: „Poziom naszego

9 lbidem, t. II, s. 452.

10 lbidem, t. I, s. 136.

11 lbidem, t. I, s. 143.

12 lbidem, t. II, s. 155, 160. 
życia w Ameryce jest o $100 \%$ wyższy niż zostawilim w Polsce. Możem sobie pozwolić o kawałek mięsa na codzień, biały chleb lepszego gatunku, owoce południa i inne rzeczy, które w Polsce są uważane za luksus. Z mojej pensji wystarcza mojej rodzinie na życie, ubranie i opłacenie podatku na dom i jeszcze mogę nieco odłożyć na nieprzewidziane potrzeby w przyszłości" ${ }^{13}$. $\mathrm{W}$ ten sposób zapewnił on sobie i rodzinie znacznie wyższy standard życia a zarazem awans społeczny.

W trakcie pierwszych dni pobytu w USA emigranci doznawali najintensywniejszych wrażeń, bowiem wtedy wszystko tam było dla nich nieznane, nowe i zaskakujące. Wygląd miast, ruch i tempo życia, wielojęzyczny tłum, inne jedzenie i ubiór, a zwłaszcza wszędzie obserwowany wyższy standard życia robił na nich duże wrażenie. Jeden $z$ nich, robotnik niewykwalifikowany $z$ Nowego Jorku, wspominał jak tam przybył „z wioski zapadłej, gdzie oprócz Kolna innego miasta nie widziałem, to wywarło na mnie wielkie wrażenie; tu subwaje pod ziemią, tramwaje na wierchu, kolej u góry, budynki wielkie, ludzi pełno gdzie się obrócić, łoskot niesłychany, okręty ryczą, woda naokoło, ulice zastawione a utami, fabryk pełno. Tu dopiero dla mnie zaczyna się Ameryka" 14.

Organista z Buffalo pisał, że od początku Ameryka „odurzyła nas wspaniałością budynków, pysznemi urządzeniami, ruchem ulicznym, hałasem itd." I nie rozczarowała w przyszłości, choć „trudno się było dorobić i majątek założyć, oprócz dostatecznego utrzymania, wygodnych mebli, fortepianu, radia, automobilu itp." 15

Robotnik sezonowy z Brooklynu, kiedy w 1927 r. wylądował w Nowym Jorku to przeżył wielki szok. Jak pisał: „Pierwsze co mi się w oczy rzuciło, brud na ulicach. Dalej niezliczone mnóstwo automobili, dym i nieprzy jemny zapach w powietrzu. Dopiero gdy doszedłem do 23 ulicy i gdy takową szedłem dalej, zauważyłem porządek tu panował. Ale automobili to jeszcze więcej jak przedtem zobaczyłem. Dziwnem mi się wydało i to, że wszystkie auta były w pośpiechu tak samo i przechodnie. Pośpiech ten na chwilę nie ustawał, jak w ulu ruch pszczół" ${ }^{16}$. Tego rodzaju wrażenia $z$ metropolii amerykańskiej były dosyć częste. Przybyszów szokował ruch, zgiełk, hałas, a przede wszystkim ogromna ilość aut, które wylewały się na drogi i szosy.

13 Ibidem, t. II, s. 430, 436 .

14 Ibidem, t. I, s. 443.

15 Ibidem, t. I, s. 390, 395.

16 Ibidem, t. I, s. 333. 
Były to wspaniałe lata dwudzieste, kiedy miliony Amerykanów mogły realizować swoje marzenia i, zgodnie $\mathrm{z}$ obietnicą Forda „taniego auta”, nabywały je masowo.

Szewc z Miami, syn kolejarza, wspominał, że po przyjeździe zobaczył nie tylko bogatą Amerykę, ale i uwierzył, że i on może żyć dostatnio, tak jak inni. Jego pierwsze wrażenia były niezapomniane. Jak pisał: „widziałem wspaniałe domki z werandami i ogródkami, które dla obcego oka nadawały uroku. W oknach firanki koronkowe w rozmaite desynie [...] sami robotnicy je zamieszku ją [...], choć trudno mi było uwierzyć, żeby robotnik mógł mieszkać w takim pałacyku. Lecz zaraz przyszło mi na myśl, że to bogata Ameryka" ${ }^{17}$. I dalej pamiętnikarz zachwycał się wyposażeniem domu, który miał okazję odwiedzić. Podziwiał w nim dywany perskie, piękne meble, wielkie obrazy święte w złotych ramkach. To wszystko wywarło na nim niezapomniane wrażenie i utwierdziło w przekonaniu, że Ameryka jest bardzo bogatym krajem, skoro tak dostatnio żyją w nim prości ludzie.

Poprawa warunków bytu emigrantów przejawiała się przede wszystkim w sposobie ich odżywiania się i podniesieniu komfortu życia, choć czasem mogli trochę przesadzać i folgować swojej fantazji. Jak pisali, przyjmowali posiłki regularnie i spożywali dużo więcej mięsa, masła, jaj, ryb, warzyw i owoców a także używek. Potem kupowali domy, ze wszystkimi udogodnieniami, oraz auta i powiększali stan posiadania swoich kont bankowych. $\mathrm{W}$ ich odczuciu stopień stabilizacji i warunków pracy oraz ilość zarobionych dolarów były faktycznym kryterium awansu i sukcesu.

Pamiętnikarze pracowali zazwyczaj w fabrykach (niektórzy z uznaniem pisali o zakładach Forda i fordyzmie, choć narzekali na tempo pracy), stalowniach, kopalniach, przy wyrębie lasu, na farmach, a czasem w restauracjach. Często zmieniali miejsca zatrudnienia, poszukując lepszych warunków, zwłaszcza płacowych. Niejednokrotnie podkreślali, że pracy się nie bali, bo byli do niej przyzwyczajeni, ale też często zastawali niezwykle trudne warunki i wy jątkowo ciężką pracę. Ale to właśnie w Ameryce, wierząc w możliwość sukcesu, potrafili zdobyć się na niewyobrażalne wyrzeczenia i poświęcenia i znosić wiele trudów, niepowodzeń, także dyskryminację. Z perspektywy wielu lat, zwłaszcza na starość i po doświadczeniach kryzysowych, pomstowali na te „nieludzkie warunki”, za które zapłacili utratą zdrowia, często kalectwem. 
Zdecydowana większość z nich, zwłaszcza ci którym się powiodło, pokazywała USA jako kraj wielkich możliwości, znakomitego systemu gospodarczego, dobrobytu, wolności politycznej i tolerancji religijnej, gdzie każdy mógł odnaleźć swoje własne miejsce, dom oraz nową ojczyznę.

Wielu emigrantów z biegiem lat stawało się zadeklarowanymi apologetami Ameryki, jej bogactwa i wszelkich możliwości, a także wolności. Utożsamiali się z Amerykanami i ich krajem, pisząc "u nas w Ameryce" albo „nasz rząd demokratyczny" ${ }^{18}$. Byli dumni, że są obywatelami „republiki Waszyngtona", korzystali z jej dobrobytu i wolności. Jeden z nich wręcz pisał, że czasem rozważał powrót do kraju, by tam „zakupić gospodarstwo i żyć bez troski resztę życia". Ale zdecydował się pozostać, gdyż jedynie w Ameryce może się czuć wolnym człowiekiem. „Jestem przyzwyczajony do wolności słowa, prasy i przekonań religijnych i politycznych. Mogę mówić i pisać co myślę bez obawy cenzury, policji i sądów. W Stanach Zjednoczonych jestem wolnem człowiekiem. Czy mógłbym być wolną jednostką w Polsce Niepodległej? Po gruntownem przemyśleniu tej sprawy przyszedłem do przekonania, że w Polsce nie miałbym tej wolności osobistej, z jakiej mogę korzystać w Ameryce. Zdecydowałem się spędzić resztę dni mojego życia na obczyźnie" 19 .

Po zmiennych kolejach losu emigranci zazwyczaj układali sobie życie i lata dwudzieste wspominali jako okres największego dobrobytu i stabilizacji, ukoronowane często zakupem wymarzonego domu. Z dumą i satysfakcją opisywali rozmaite udogodnienia i wyposażenie mieszkania, zwłaszcza, jak pisał jeden $z$ nich, „elektryczne oświetlenie, gaz do gotowania, wannę i. wygódkę. Jest przy tym piękny kredens w kuchni i nieduża spiżarnia [...]. W domu mamy również piękne i miłe urządzenie, posiadamy przy tem telefon $[\ldots] "{ }^{20}$.

Inny także podkreślał dobrobyt materialny jego rodziny i kolejne zakupy, m.in. dwa radia (do domu i auta) oraz lodówkę, które uprzyjemniają i ułatwiają życie. Z dumą pisał, że elektryczność „służy do pożytecznych rzeczy", bowiem używa się jej „do zamiatania i czyszczenia dywanów, do prasowania, do przysmażania chleba, do rurkowania włosów, do gotowania w niektórych domach, do prania bielizny i maglowania". I w konkluzji retorycznie zapytuje: „Czy będąc w Polsce z nieskończonym gimnazjum mógł-

\footnotetext{
18 Ibidem, t. II, s. $214,309-310,492 \mathrm{i}$ in.

19 lbidem, t. II, s. 309-310.

20 Ibidem, t. II, s. 191.
} 
bym mieć co tutaj posiadam? Mógłbym odbywać podróże, mieć eleganckie auto i dom?" 21 .

Fryzjer z Buffalo, syn chłopa małorolnego, pisał tak: „Jakkolwiek mało zarabiam, to jednak mój poziom życiowy tak obecnie, jak i poprzednio jest znacznie wyższy niżeli w kraju, pod względem odżywiania i ubierania się, wy jąwszy okresy bezrobocia. Mniemam, że pod względem dobrobytu, Stany Zjednoczone przewyższają wszystkie narody cywilizowane" ${ }^{22}$. I dalej deklarował, że z pobytu ,jestem zupełnie zadowolony, tak pod względem materialnym, jak i duchowym. Wprawdzie, iz nie posiadam prawie nic, ale to pochodzi raczej z mojej nieporadności, a nawet niedbałości, gdyż biorąc na ogół, to tu nikt nikomu nie stawia zbyt wielkich przeszkód na drodze do kariery $\mathrm{np}$. $\mathrm{w}$ takim stopniu, jak to było za mojego pobytu w kraju, gdzie dla wyrobnika niemal wszystko było zamknięte. Natomiast tu, ci sami wyrobnicy, fornale, włodarze (rataje) zdobyli pokaźne majątki, np. 50 tys. w gotówce, lub - realności i wzwyż, oraz stanowiska bądź w przemyśle, bądź w społeczeństwie. W niektórych wypadkach nie posiadając elementarnego wykształcenia natomiast mając energię i ambicje, tacy więc ludzie zdobyli stopniowo wykształcenie i majątki lub stanowiska [...]" 23 .

Ewidentnym i widocznym świadectwem sukcesu większości pamiętnikarzy był zakup samochodu, czemu poświęcali sporo uwagi. Jak wspominał jeden z nich: „W roku 1928 kupujemy wreszcie nasz pierwszy automobil moje marzenie kilku ostatnich lat. Któż nie słyszał, że w Ameryce niemal wszyscy posiadają auta i jeżdżą niemi na wycieczki i podróże. Rzeczywiście, automobil jest tu tak powszechną rzeczą jak kon i wóz w dawnej Galicji. Każdy niemal biedniejszy czy bogatszy pragnie posiadać auto, gdyż jest to bardzo wygodna i pożyteczna rzecz" 24.

Inny pamiętnikarz mówił również o sobie jako człowieku zrealizowanym, który na obczyźnie odniósł sukces. Z nieukrywaną satysfakcją pisał, że w swoim domu wprowadził rozmaite innowacje i udogodnienia, m.in. „automatyczny przyrząd do opalania olejem skalnym”. I dalej wyliczał: „W mieszkaniu mamy radio na prąd stały. Również mamy elektryczny patefon, elektryczną pralnię i żelazko do prasowania, elektryczną miotłę do zamiatania a nawet rurki do kręcania włosów ma żona także elektryczne. Posiadamy automobil nowy z roku 1936, pięcioosobowy marki «Dodge», już trzeci z kolei,

21 Ibidem, t. II, s. 223.

22 Ibidem, t. I, s. 412.

23 Ibidem, t. I, s. 415.

24 Ibidem, t. II, s. 192. 
gdyż każdego roku wychodzą nowe ulepszenia automobilowe i chcąc dostosować się choć trochę do ogólnego postępu, trzeba automobil chociaż co cztery lub pięć lat zmieniać [...]. Ogromnie lubię prowadzić auto, ma się rozumieć po dobrych drogach" 25 .

W konkluzji autor pisał: „Stopa życiowa przeciętnego polskiego chłopa emigranta, a obecnie już najczęściej obywatela amerykańskiego, jest wysoka. Mieszka sobie w czterech a nierzadko sześciu pokojach nowoczesnych $\mathrm{z}$ łazienką, ma ładne umeblowanie, odżywia się dobrze (potrawy mięsne każdego dnia), ubiera się też porządnie na niedzielę, a jego córki trzymają się ściśle ostatniego krzyku mody. W każdym domu mają radia, które wskutek masowej produkcji nie są drogie" ${ }^{26}$. Jak z tego widać, pamiętnikarz uważał się za człowieka zrealizowanego, który w Ameryce, podobnie jak wielu rodaków, odniósł sukces. Zrealizował swoje marzenia, a przede wszystkim zabezpieczył lepszy byt swojej rodzinie.

Komiwojażer z Los Angeles już jako 15-letni chłopak opuścił swój dom rodzinny (okolice Tarnopola) i późniejsze życie spędził poza krajem, najpierw w Prusach, potem pływając po morzach w służbie okrętowej, skąd trafił do Ameryki. Dosyć enigmatycznie pisał o swoich zarobkach, choć wyrażał zadowolenie $\mathrm{z}$ pobytu w USA. „Stopa życiowa jest tu dość wysoka w proporcji do robotnika polskiego - gdzie tu się widzi prawie u wszystkich dom umeblowany, radio, automobil, fotele, dywany itp. i jest rzadkością, zwłaszcza tu w Los Angeles, ażeby ktoś nie posiadał automobilu i to bez względu czy pracuje czy jest na utrzymaniu stanowym" 27. Pisał też, że trudno by mu było „Z wyższej stopy życiowej amerykańskiej przystosować się do polskiej”, choćby z powodu biurokracji, uniżoności, „czapkowania i całowania rączek", a także braku wolności religijnej w "starym kraju”. Był już na tyle zamerykanizowany, że to wszystko go raziło, a także pycha, zarozumiałość oraz brak punktualności rodaków, jak utyskiwał ${ }^{28}$.

Pamiętnikarze z nieukrywaną satysfakcją pisali o swoich sukcesach i zarobionych dolarach, powiększających ich konta bankowe oraz służących zaspokajaniu kolejnych życiowych potrzeb, o których w Polsce, co podkreślali, nie mogliby nawet marzyć. Niejednokrotnie szczegółowo podawali ile za co zapłacili, co nowego kupili do gospodarstwa lub jak ubrali swoje małżonki

25 lbidem, t. I, s. 184-185.

26 lbidem, t. I, s. 190.

27 Ibidem, t. II, s. 587.

28 lbidem. t. II, s. 587. 
(modne stroje, jedwabie, kapelusze, futra karakułowe etc.). Jeden $z$ nich nawet twierdził, że żyje tak wygodnie i w takim dostatku, że nie wie „czy pan Hrabia miał lepiej za moich czasów w Polsce" ${ }^{29}$. Bo właśnie Polska i społeczność lokalna, z której pochodzili, były punktem odniesienia pamiętnikarzy. W zasadzie nie porównywali oni swego położenia i sytuacji materialnej do Amerykanów. Być może dlatego, że nie orientowali się zbytnio w ich realiach, ale również dlatego, że wtedy nie mogliby się zbytnio chwalić swoimi osiągnięciami, bo takie porównanie byłoby znacznie mniej korzystne.

Emigranci przez lata tęsknili za krajem i marzyli, by odwiedzić już wolną Polskę po I wojnie światowej. Niektórzy decydowali się nawet na powrót, ale rozczarowani z panujących w niej warunków, często oszukani przez urzędników, ponownie wracali do Ameryki „narzekając na swoich krewnych, na złe stosunki w Polsce, złe obchodzenie się z nimi, to znowu na brak sanitarnych urządzeń - mówiąc przy tem, że rodak z Ameryki jest niemile widziany w Polsce" ${ }^{30}$. Inni z kolei odwiedzali tylko rodziny i krewnych w Polsce, zwiedzali historyczne miejsca i wywozili ze sobą pamiątki za ocean. Nierzadko też mieli bardzo przykre doświadczenia i przygody, kiedy rozmaici złodzieje i oszuści chcieli ich okraść z dolarów. Nawet w Urzędzie Celnym dochodziło do prób zawłaszczenia ich dorobku, jak z oburzeniem wspominał jeden $\mathrm{z}$ nich, który nie pozwolił „sobie nic konfiskować, ani jednego centa, bo to jest moja własność, zapracowana w Ameryce ciężką pracą" ${ }^{31}$.

Emigranci, kiedy odwiedzali kraj, przeżywali nieraz rozliczne rozczarowania i zawody, zwłaszcza z powodu niewygód życia, biedy, biurokracji etc. Krawiec z Nowego Jorku, odwiedzając Kraków, pisał tak: „Jakie maleńkie budynki w porównaniu $\mathrm{z}$ drapaczami nieba w New Yorku. Stoimy w hotelu w jakimś biednym ani łazienki, nareszcie moja połowica dostała kąpiel, ale strasznie zaczęła narzekać" ${ }^{32}$. Jeszcze większe rozczarowanie czekało go, kiedy wybrał się, by odwiedzić teściów we wschodniej Galicji. Natychmiast też podjął z żoną decyzję o powrocie do Ameryki, która przyciągała nie tylko z powodu swego bogactwa i wygód, ale i wydała im się „jakaś bliska”. Warto dodać, że przy okazji odwiedzin „starego kraju” emigranci nieraz określali i definiowali swój stosunek do Ameryki, która stawała się ich nową ojczyzną.

Robotnik, syn chłopa z Małopolski, po krótkim pobycie w Ameryce postanowił tam pozostać na zawsze. Już wkrótce ożenił się z "polską panienką"

31 Ibidem, t. I, s. 304.

32 Ibidem, t. I, s. 463.
} 
i zaczął, jak wspominal, „bardzo wesołe i dobre” życie. Mając stałą pracę i regularne dochody, zakupił dom i wyposażył go w nowe meble i rozmaite urządzenia. Potem w latach prosperity wymienił dom na większy, lepszy, w bezpiecznej dzielnicy. Jak podkreślał, zawsze „inwestował” w dzieci, dając im wykształcenie, by sobie lepiej radzili w realiach amerykańskich ${ }^{33}$.

Podobnie też pisał tokarz wykwalifikowany: „Moim pragnieniem było, aby dać dzieciom o ile możności wyższe wykształcenie, aby nie byli szuflarzami, bo człowiek bez wykształcenia nie ma żadnego znaczenia, a żywot ma bardzo ciężki" ${ }^{34}$. I tak też uczynił, co potem podsumował, że zamiast „dojść do majątku" poniósł „olbrzymie koszta”, by dać dzieciom wyższe wykształcenie. Ale był z tego powodu szczęśliwy i dumny ${ }^{35}$.

Agent ubezpieczeniowy z Lowell, syn chłopa małorolnego, przebywający w USA prawie 40 lat, nie miał powodów - jak zapewnial - by narzekać na swoje położenie. W Ameryce dorobił się, miał własny dom ze wszelkimi wygodami, pięknie umeblowany. Pisał tak: „Tu trzeba zaznaczyć, że kto raz pobędzie dłuższy czas w Ameryce, to w kraju nie usiedzi. Bo co prawda, to w Ameryce można lepiej żyć pod każdem względem. Znam dużo ludzi z rodzinnej wioski, którzy dorobili się dużego majątku. Mają swoje ładne domy i prowadzą własne interesa, czego by się w Polsce nigdy nie dorobili" ${ }^{36}$.

Pamiętnikarz, który w Ameryce osiągnął prawdziwy sukces był tkaczem, a później doktorem medycyny. W 1906 r. wyjechał do USA za pożyczone pieniądze. Tu zdobył doświadczenie i wykształcenie, co umożliwiło mu zupełnie inny start życiowy i znacznie lepsze warunki. Jak pisał: „Faktycznie nam tu w Ameryce dobrze jest. Kraj bogaty, świetnie zagospodarowany; wszystkiego jest pod dostatkiem; udogodnienia na każdym kroku ogromne; komunikacja świetna; drogi idealne. Mimo kryzysu tu jest dobrobyt. $\mathrm{Na}$ każde pięć osób przypada jeden automobil. Aparat radiowy znajduje się nieomal w każdym domu. Przeciętna rodzina robotnicza zajmuje dom, lub piętro, o pięciu lub sześciu pokojach. Praca domowa kobiet jest niezmiernie ułatwiona dzięki przeróżnym aparatom elektrycznym. W ogóle elektryka spełnia tu większą część pracy domowej; elektryka pierze i prasuje bieliznę, czyści dywany, podłogi i ściany, wytwarza lód sztuczny, etc. etc." ${ }^{37}$.

33 Ibidem, t. I, s. 471.

34 Ibidem, t. I, s. 477

35 Ibidem, t. I, s. 478.

36 Ibidem, t. I, s. 199.

37 Ibidem, t. I, s. 255-256. 
I w konkluzji lekarz z satysfakcja pisał o swojej drodze życia i podkreślał, że był zadowolony z pobytu w USA. „Wyjechałem z Polski z gołymi rękami, za pożyczone pieniądze. Tu na obczyźnie znalazłem chleb, znalazłem sposobność do nauki, ukończyłem wyższą szkołę, dochowałem się rodziny, mam własny dom, automobil i radio i dość dobrze mi się powodzi" ${ }^{38}$.

Żona murarza z Detroit, po wielu perypetiach w Ameryce, ostatecznie wszak uznała, że: „Poziom życia robotnika wyższy pod każdym względem. $\mathrm{Na}$ automobil w lepszych czasach też sobie może pozwolić, który nie jest luksusem, ale potrzebą, jak konie gospodarzowi na wsi. Więcej robotnik ma, ale też pracuje więcej i ciężej niż w Polsce. Czas w przeciwieństwie do Polski jest drogi i ludzie pracują chętnie o ile mają sposobność, często bez względu na jakość pracy. W Polsce czasu się nie ceni tak wysoko jak tutaj. Pamiętam jak byłam w starostwie, załatwiając sprawy związane $\mathrm{z}$ wyjazdem, widziałam ludzi ze wsi czekających godzinami na korytarzu, aż ich się kto zapyta z czem przybyli” 39. W konkluzji stwierdziła: „Przychodzę do wniosku, że jeżeli w Ameryce jest dobrze to lepiej niż w Polsce, a jeśli źle, to gorzej" 40. I w tej opinii nie była odosobniona.

Warto dodać, że pamiętnikarze nieraz podkreślali, iż wszelkie wygody i. komfort życia szczególnie doceniają ich żony i córki. Jeden z nich, nie bez pewnej uszczypliwości, ale i dumy, wspominał: „żona moja do Ameryki przylgnęła jakby tu była urodzona. Przejęła się różnymi ulepszeniami jakie sa w Ameryce. Byłoby jej trudno dostosować się chodząc po wodę jak to było w Ostrowcu lub Iłży. Trudno jej byłoby obejść się bez mleka puszkowego i innych przyborów do kuchni. W Ameryce kobiety mają pracę w domu taką jak magik na scenie, co splunie w kapelusz a wy jmie $z$ niego jajecznicę. Kuchnia w Ameryce jest pod tym względem dla kobiet dobrodziejstwem, że ma wszystko pod ręką, tego doleje, tego doda, tamtego przysypie, innym posmaruje, czym innym przystroi i obiad gotowy. Gaz i elektryka musi być wszędzie aby kobiety nie dmuchały pod garnki jak to bywało w Iłży, lub na farmie w Orwel. Prania kobiety tu nie znaja jak to w Polsce, pranie odbywa się za pomocą maszyny, prasowanie maszyną lub żelazkiem elektrycznym, zamiata się miotłą elektryczną, która wciąga w siebie wszystkie nieczystości. Każda z pań musi mieć radio [...]" ${ }^{41}$. Oczywiście były to wspaniałe lata

\footnotetext{
38 Ibidem, t. I, s. 261.

39 Ibidem, t. II, s. 452.

40 Ibidem, t. II, s. 454.

41 Ibidem, t. II, s. 81-82.
} 
dwudzieste, okres powojennej prosperity, kiedy wprowadzano rozmaite udogodnienia, nowinki techniczne i mechanizację, dzięki czemu życie przeciętnej rodziny amerykańskiej stawało się łatwe i przyjemne.

Ale nie wszystkim w Ameryce, nawet w okresie największej prosperity, powodziło się dobrze i żyło dostatnio. Niektórzy pamiętnikarze, rozczarowani i rozgoryczeni Ameryką, która nie spełniła ich marzeń, przedstawiali ja jako kraj ciężkiej pracy i wyzysku człowieka, gdzie byli źle traktowani i dyskryminowani przez pracodawców i urzędników. Szewc, właściciel warsztatu w Manchester wręcz ostrzegał rodaków w kraju: „nie myślcie, że my tu na obczyźnie opływamy w rozkoszach", choć są i tacy, jak wspomina, co dorobili się majątku. Jak podkreślał: „ustrój tutejszy społeczny jest taki, że tylko tyle ci dadzą, abyś z głodu nie umarł" 42.

Inny pamiętnikarz, któremu się nie powiodło, pisał również o swojej niedoli w Ameryce. Popadł on w biedę, wręcz głodował, i pożyczył parę dolarów na przeżycie, kiedy matka przysłała list z Polski i prosiła o pieniądze. Jak wspominał autor: „Odpisałem, że się postaram niezadługo przysłać, nie wspominając nic o swojej biedzie. Zresztą gdybym nawet pisał, że mnie tu źle, to tam wszystko jedno by nie uwierzyli. W kraju myślą, że w Ameryce jest bardzo dobrze i niczego nie braknie" 43 .

Kolejne lata nie dały mu żadnej stabilizacji, a doraźne prace pozwalały mu jedynie na przeżycie. Nawet fakt, że opanował nieźle język angielski nie polepszył mu sytuacji życiowej, jak skonstatował, a jedynie pozwolił poznać lepiej tamtejsze życie i obyczaje. Z czasem coraz krytyczniej pisał o Ameryce, gdzie panowała „gorączka za dolarami” i „królował pieniądz”. Jego zdaniem: „Tutaj człowiek to maszyna, która bezskutecznie się porusza. Człowiek, który zapomniał o sobie, a żyje dla dolara. Ta chęć posiadania tego martwego, zielonego kawałka papieru, pozbawia go wszelkiego uczucia, wszelkiej przyjemności. Dla dolara wszystko oddaje. Tutaj gdy nie masz pieniędzy, choćbyś prowadził siebie najwzorowiej, choćbyś był najwięcej wykształconym, nic nie wart jesteś" 44.

Właściciel zakładu szewskiego, socjalista, laureat konkursu, swoje początki w Ameryce wspominał tak: „Żyłem bardzo oszczędnie, bo tylko owocem i chlebem, rozumiałem już, że jak będę miał pieniądze to będę miał przy jaciół, rozumiałem, że do Ameryki kto przybędzie, a nie będzie miał

42 Ibidem, t. I, s. 122-123.

43 Ibidem, t. I, s. 341.

44 lbidem, t. I, s. 344. 
serca szczura, ten nie zrobi żadnego sukcesu" ${ }^{45}$. Jego trudne początki nie znajdowały zrozumienia rodziny w Polsce, która spodziewała się od niego wsparcia finansowego. Jak pisał wszyscy oni „myśleli, że w Ameryce garnie się pieniądze szuflą jak plewy, drudzy pisali o karty okrętowe do Ameryki, wszyscy tylko myśleli o wyjeździe do Ameryki, nie wierzyli że ja nie mam pieniędzy [...]" 46 .

Bodaj najbardziej krytycznie o „raju amerykańskim” wypowiedział się tramp, wędrujący stale po Ameryce. O swojej pracy kelnera pisał, że dawała mu „sposobność, że tak powiem - brać udział pośrednio w tem, co ludzie nazywają estetyką, życiem wyższej kultury, choć inni nazywają to także wyuzdaniem i zwyrodnieniem. Uczty lukulusowe, neronowe i saturnalia opisywane przez fantastów beletrystycznych, nie były dla mnie jedynie wytworem wyobraźni; widziałem je, dotykałem je, smakowałem własnym językiem. Widziałem tych nowoczesnych patrycjuszów i plutokratów, ich żony, córki, synów i konkubiny, jak ży ją i jak się bawią i intrygują, bez żadnej konwencjonalnej restrykcji, gdyż kelner w ich umysłowości jest tylko rzeczą, którą się kupuje i wyrzuca kiedy przestaje być wygodną albo staje się być szkodliwą" ${ }^{47}$. Mimo tych ostrych i gorzkich słów o kraju, gdzie wielkie fortuny "królów węglowych" powstały z "potu i krwi” także polskich emigrantów, i gdzie „nie pytają kim jesteś, tylko ile masz”, wolał Amerykę. Co więcej, jak zapewniał, „dwa lata pobytu w Polsce przekonały mnie, że się do Polski nie nadaję" ${ }^{48}$. Wolał po prostu wygodne życie w przybranej ojczyźnie.

Inny pamiętnikarz (wcześniej właściciel sklepu, a potem mieszkaniec przytułku) pisał, że w Ameryce trzy razy dorabiał się i wreszcie stracił wszystko w latach kryzysu gospodarczego. Jak podsumował: „W Ameryce prędko można zarobić pieniądze i prędko zgubić. Tu dziewczyny zarabiają nieźle, stroją się w atłasy, jedwabie, chodzą do pracy przewyższają milionerki w stroju. Tak w Ameryce kto miał szczęście, to wielkiego majątku się dorobił, a niektórzy z głodu umierają albo życie odbierają sobie. Ja sam już straciłem wszystko, żona trzy razy była operowana, całe życie potrzebowała doktorów" 49.

\footnotetext{
45 Ibidem, t. II, s. 53-54.

46 Ibidem, t. II, s. 58.

47 Ibidem, t. II, s. 117.

48 Ibidem, t. II, s. 134.

49 Ibidem, t. II, s. 141.
} 
Robotnik z Chicago, syn chłopa małorolnego z zaboru rosyjskiego spędził 30 lat w Ameryce, ale nie dorobił się tam fortuny i był na zasiłku rządowym. Z filozoficznym wręcz spokojem pisał o doli i niedoli rodaków: „Będąc za granicą nauczyliśmy się wielu rzeczy, które umożliwiły nam pewien dobrobyt. Dużo z nas nie miało wielkiego szczęścia, dlatego też dzisiaj musimy być na łasce rządu amerykańskiego, który kochamy i poważamy jako swój własny rząd. Stany Zjednoczone lubimy, bo tu spędziliśmy wiele lat swego najlepszego życia. Wielu z nas jedzie do Polski na wycieczkę, bo tęsknota za Ojczyzną i stronami rodzinnemi nie daje nam spokoju, jednak wracają oni tu, bo łatwiej się tu żyje i wygodniej aniżeli tam w Polsce, gdzie bieda dokucza wszystkim, szczególnie chłopom" 50.

Pamiętnikarze żyli w „swojej” Ameryce, najczęściej w polskiej dzielnicy, z własną parafią, szkołą, siecią usług etc. Mieli kontakt zazwyczaj ze swymi rodakami, a niewielu $z$ nich ze środowiskiem amerykańskim. Większość z nich była zadowolona ze swojej sytuacji materialnej i podkreślała, że mieli własne duże i wygodne domy, często też auta oraz sporo oszczędności w bankach. Niektórzy nawet pisali, że ich sytuacja materialna była „bardzo dobra", zwłaszcza ci, którzy mieli dobre posady i pobory oraz posiadali domy. Wielu z nich podkreślało, że przez lata, w miarę swoich możliwości, wspierali finansowo rodziny w kraju.

Tylko nieliczni w zdobyciu wykształcenia widzieli szansę na własny awans, ale większość z nich widziała taką potrzebę i realną szansę dla swoich dzieci, którym starali się zapewnić edukację. Ich dzieci i następne pokolenia będą znacznie łatwiej radzić sobie $\mathrm{z}$ adaptacją $\mathrm{w}$ miejscowym środowisku, co zarazem oznaczało postępu jącą amerykanizację.

Pamiętnikarze nierzadko utyskiwali na warunki pracy i amerykański system, ale jeśli ich zarobki były wysokie to jakoś to im rekompensowało ten trud. Summa summarum uważali się za ludzi sukcesu, zwłaszcza jeśli porównywali swoje osiągnięcia w odniesieniu do realiów polskich. Znacznie bardziej krytyczni wobec Ameryki, zgorzkniali i zawiedzeni byli natomiast „nieudacznicy" oraz ci, którzy ulegli wypadkom lub zaczęli chorować. Dla nich Ameryka, także przed kryzysem gospodarczym, stawała się „krainą łez" i krajem „wyzysku człowieka".

W czasie kryzysu gospodarczego warunki materialne prawie wszystkich pamiętnikarzy pogorszyły się, zazwyczaj zresztą dosyć drastycznie. Tracili oni pracę (na miesiące albo i lata; czasem pracowali dorywczo) oraz swoje

50 Ibidem, t. II, s. 305. 
oszczędności, nieraz także domy (bo nie byli w stanie spłacać kredytów). Niektórzy znaleźli się nawet w bardzo trudnej sytuacji, w skrajnej nędzy i korzystali z zapomóg dla bezrobotnych. Zazwyczaj też chwalili za to prezydenta Roosevelta i reformy „Nowego Ładu”, przy okazji podziwiali pracowitość i zaradność Amerykanów oraz amerykański system, który sprawdzał się także w trudnych czasach.

I choć dla wielu pamiętnikarzy ich nowa ojczyzna przestała być wyśnionym obiektem marzeń i zachwytu (z nostalgią wszak wspominają lata dwudzieste - okres świetności, dobrobytu i dostatku), to i tak uważali ją za lepsze miejsce do życia. Pisali nieraz wprost (mając jako punkt odniesienia kraj, a ściślej sytuację w ich rodzinnej wsi, czasem nawet sprzed wielu lat), że żyło się im tutaj lepiej niż w Polsce. Zachwycali się amerykańską inżynierią, technologią i mechanizacją, zwłaszcza autami, robiącymi karierę na całym świecie. Z dużą satysfakcją pisali o swoich coraz bardziej zasobnych domach, meblach, sprzęcie zmechanizowanym, a także kontach bankowych, które niewątpliwie świadczyły o ich sukcesie i awansie. To była ich Ameryka, własna i niepowtarzalna. Jak ktoś powiedział, taka, jaką sobie wymarzyli albo na jaką sobie zasłużyli. I było tych Ameryk tyle, ile wyobrażeń oraz doświadczeń pamiętnikarzy o tym kraju. 